\title{
Correspondence
}

\section{Implications of the Bournewood decision}

Sir: The House of Lords is due to deliver a decision in June on the case of $L$. $v$. Bournewood Community and Mental Health NHS Trust. It is expected to uphold the Court of Appeals decision that a hospital could informally admit a person for treatment for a mental disorder under section 131 of the Mental Health Act only with his consent (The Times, Inability to consent makes detection illegel. L. $v$ Bournewood Community and Mental Health NHS Trust, 8 December 1977).

In the meantime, it is clear that it is unlawful to detain patients without capacity as informal patients and that there are many informally detained in-patients whose capacity to consent ought to be reviewed. I have been told by one second opinion doctor that he has been asked by the Mental Health Act Commission if he would be prepared to work on weekends! This is hardly surprising.

However, the more far reaching implications in having a dramatic increase in the number of formally detained in-patients are likely to impact on all health care workers within the psychiatric services. First, there is the added burden of the paperwork involved in preparing the section documentation. Second, increased time will have to be spent attending mental health tribunals, not to mention the effect that these tribunals will have on the Lord Chancellor's legal aid budget.

If the House of Lords uphold the court of appeals decision, is there not a case for the introduction of a new section in the Mental Health Act which pertains to those patients who lack the capacity to consent or dissent?

Damian MoHan, Lecturer in Forensic Psychiatry, University of Southampton and Broadmoor Hospital, Professorial Unit, Broadmoor Hospital, Crowthorne, Berkshire RG45 7EG

Sir: The Court of Appeal's judgement in Leboff $v$. Bournewood Community Mental Health Trust if implemented (depending on Law Lord's Judgement) has serious implications for patients with severe mental impairment and some with moderate degree of mental impairment, who lack capacity to consent for admission to hospital for assessment and treatment of their 'mental disorder'.

In my view, there are at least three approaches to the Appeal Court's Judgement which could be used to bypass the potential use of sectioning orders (section 2/3 mainly) of the Mental Health Act 1983, in order to detain, mainly long-term patients in hospitals who have been there for many years on a voluntary basis.

(a) Those patients who do not require or need assessment may be discharged, imposing an enormous burden on social services and relatives to find community accommodation.

(b) The Welsh Office Circular of 22.1.98 WHC (98) on page 2 (iii) states "in an emergency if patient lacks the capacity and no application for admission under the Act is made, a hospital is able to look after the patient to prevent him or her from harming themselves, until other reasonably satisfactory arrangements can be made". As there is no specific time for discharge stated this can be perhaps interpreted in a much wider sense.

(c) Sections of hospitals could be designated as residential. Residents who were properly assessed by their responsible medical officers are no longer labelled as 'patients', and therefore the Mental Health Act in their case does not apply.

The Court of Appeal judgement affects only those patients who lack capacity to consent for admission for assessment and treatment to hospital, but what about patients living in the community and who receive psychotropic medication or other treatments? In fact when all the hospitals eventually close, all such people with mental impairment with or without capacity to consent will be assessed and treated in community-based accommodation. A clear and legally fair and just law for these vulnerable sections of society is an urgent requirement.

T. H. Singh, Consultant Psychiatrist, Bridgend and District NHS Trust, Learning Disability Services, Hensol, nr Pontyclun, Mid Glamorgan CF72 8YS

\section{Improving treatment adherence among patients with chronic psychosis}

Sir: I read Sair et al's article (Psychiatric Bulletin. February 1998, 22, 77-81) on compliance with interest. The authors rightly note the move away from the authoritarian connotations often 
associated with compliance but failed to introduce this concept of 'concordance', which has been advocated as a more collaborative, consensual, psycho-educational term (Mullen, 1997). Likewise although the importance and impact on non-compliance is described, Buchanan's work in asserting that compliance in schizophrenia is no worse than in any other chronic medical disorder (Buchanan, 1996) was not mentioned. The notion that people with schizophrenia form part of a general medical population where compliance is a challenge helps prevent the negative labelling of people with mental disorders as poor compliers. This is surely part of reducing the stigma of mental illness.

Buchanan, A. (1996) Compliance with Treatment in Schizophrenia. Maudsley Monograph no. 37. London: Psychology Press.

MULLEN, P. D. (1997) Compliance becomes concordance. British Medical Journal, $\mathbf{3 1 4}$.

C. J. HALEY, Senior Registrar in Adult Psychiatry, University of Liverpool, Department of Clinical Psychology, The Whelan Building, Quadrangle, Brownlow Hill, Liverpool L69 3GB

\section{Body decoration and intravenous drug misuse}

Sir: Williams (Psychiatric Bulletin, January 1998, 22, 94-96) describes tattoos and body adornment among psychiatric admissions. We surveyed an opportunistic sample of 50 drug users attending a community drug team, systematically recording details of tattoos, tattooing practice and body piercing. The sample comprised 41 men and nine women, with an average age of 28.9 years. Forty-four had histories of intravenous drug use.

The maximum number of tattoos was 20 in women and 25 in men. Thirty-two subjects had tattoos of real or mythical animals, 30 were tattooed with family member's names, 27 with their own first name, 11 with their own nickname, and nine with gang names. Sixteen were tattooed with drug-related names or pictures: cannabis leaves, syringes and psilocybin mushrooms being the most common. Twenty-eight men and two women had been tattooed in prison.

Forty-six subjects had pierced ears, seven a pierced nose, five men and one woman pierced nipples, and three men pierced genitals. The maximum number of piercings was 16 in men and 13 in women. Sixteen drug injectors with piercings had failed to use basic sterile precautions when body piercing, whereas all six noninjectors had always used aseptic techniques.
That drug injectors are less careful about sterile technique during body piercing must cause concern.

BERNADETTE CANTWELL, formerly medical student, C/O Community Addiction Unit, Whitchurch Hospital, Cardiff CF4 7XB; JULIAN H. RACE, Consultant Psychiatrist, North Wales Hospital, Denbigh LL16 5SS; and ANDREW J. MCBRIDE, Community Addiction Unit, Whitchurch Hospital, Cardiff CF4 7XB

\section{Research by senior registrars in psychiatry}

Sir: Williams \& Curran (Psychiatric Bulletin, February 1998, 22, 102-104) draw a number of conclusions from their questionnaire survey, which they feel may be helpful and relevant to the training needs of specialist registrars. However, their data may support other conclusions. I note that only one-third of respondents admitted to performing research for their own interest; the other two-thirds were apparently motivated for 'curriculum vitae' purposes, to 'advance career' or even to 'please others'.

My experience is that many higher trainees have an extremely ambivalent attitude towards research. While recognising the necessity of being able to critically analyse research, many trainees have no intention of performing research as a consultant (and probably will not have the time), yet feel compelled to 'go through the motions' of (at least appearing) to conduct research, as this is expected of them. If the research is completed (and with poor motivation, much is not), it is often of poor quality and of little clinical use.

If there are lessons to be learnt from the senior registrar grade, then perhaps encouraging and facilitating higher trainees to use their study day in a way which would be most useful to them as individuals (taking into account their career plans) should be one. Surely it is time to stop trying to force too many square pegs into the round (black) holes of research.

DAVID LAWLEY, Senior Registrar in Psychiatry, Bootham Park Hospital, York YO3 7BY

\section{Work of the Mental Health Act Commission}

Sir: We were surprised by the letter from Tyrer and colleagues (Psychiatric Bulletin. February 1998, 22, 118-119), and cannot agree with their criticisms of the work of the Mental Health Act Commission. We do not see that either the increased pressure on beds or the introduction of new statutory review procedures makes the 